\title{
Characterization of wellbeing in the youth population of the metropolitan area of Porto
}

\author{
Beatriz Couto $^{1 *}$ (iD), Maria João Trigueiro ${ }^{1,2}$ (D) , Vítor Simões-Silva $^{1,2}$ (i) , António Marques ${ }^{1,2}$ (i) \\ 'Escola Superior de Saúde do Politécnico do Porto, Porto, Portugal; \\ 2Laboratório de Reabilitação Psicossocial do Politécnico do Porto, Porto, Portugal. \\ *Autor correspondente/Corresponding author: 10150147@ess.ipp.pt
}

Recebido/Received: 23-07-2021; Revisto/Revised: 09-09-2021; Aceite/Accepted: 16-09-2021

\begin{abstract}
Resumo
Introdução: $O$ bem-estar é um conceito multidimensional que pressupõe que o indivíduo deve envolver-se no seu dia-a-dia e encontrar significado e propósito nas suas ocupações através da construção de uma identidade pessoal e da manutenção de papéis socialmente valorizados. Objetivo: Este é um conceito recente e ainda pouco estudado, pelo que o objetivo deste estudo é descrever a prevalência do nível de bem-estar da população jovem, entre os 14 e os 18 anos, na Área Metropolitana do Porto. Material e Métodos: Realizou-se um estudo transversal em 847 jovens de escolas secundárias do Porto, Vila Nova de Gaia, Matosinhos e Gondomar, sendo utilizadas duas escalas de avaliação do bem-estar, as versões portuguesas da Warwick-Edinburgh Mental Wellbeing Scale e do Pemberton Happiness Index e um questionário sociodemográfico, de autopreenchimento. Resultados: Verificaram-se diferenças estatisticamente significativas nos níveis de bem-estar relativamente às variáveis sexo $\left(\mathrm{p}_{\mathrm{wenws}}<0,001 ; \mathrm{p}_{\mathrm{PH}}<0,001\right)$, conhecer alguém com problemas de saúde mental ( $\left.p_{\text {WEMws }}<0,001 ; p_{\text {PHI }}<0,001\right)$, grau de escolaridade $\left(p_{\text {wenws }}<0,031\right)$ e cidade de residência ( $p_{\text {WENws }}$ $\left.<0,045 ; p_{\mathrm{PHI}}<0,011\right)$. Conclusão: Identificou-se que ser jovem do sexo masculino, não conhecer indivíduos com problemas de saúde mental e possuir um menor grau de escolaridade são preditores significativos de bem-estar.
\end{abstract}

Palavras-chave: bem-estar; jovens; Escala de Bem-Estar Mental de Warwick-Edinburgh; Índice de Felicidade de Pemberton; prevalência.

\begin{abstract}
Introduction: Wellbeing is a multidimensional concept that assumes that the individual must be involved in his or her daily life and find meaning and purpose in his or her occupation by building a personal identity and maintaining socially valued roles. Objective: This is a recent concept and still little studied, so the purpose of this study is to describe the prevalence of wellbeing in young people between 14 and 18 years old in the metropolitan area of Porto. Material and Methods: This was a cross-sectional study of 847 young people from secondary schools in Porto, Vila Nova de Gaia, Matosinhos, and Gondomar. Two wellbeing assessment scales, the Warwick-Edinburgh Mental Wellbeing Scale and the Pemberton Happiness Index, and a self-filled sociodemographic questionnaire were used. Results: Statistically significant differences were found regarding sex $\left(p_{\text {WEMws }}<0.001 ; p_{\text {PHI }}<0.001\right)$, knowing someone with mental health problems ( $\left.p_{\text {WEMWS }}<0.001 ; p_{\text {PHI }}<0.001\right)$, education level $\left(p_{\text {WEWWS }}<0.031\right)$, and city of residence $\left(p_{\text {WEWWS }}<0.045 ; p_{\text {PHI }}<0.011\right)$. Conclusion: Young males not knowing individuals with mental health problems and having a lower level of education were significant predictors of wellbeing.
\end{abstract}

Keywords: wellbeing; young; Warwick-Edinburgh Mental Wellbeing Scale; Pemberton Happiness Index; prevalence.

\section{INTRODUÇÃO}

O conceito de bem-estar, embora comummente usado, ainda é um termo ambíguo na literatura (Dodge et al., 2012; Pollard and Lee, 2003). É definido sobre várias perspetivas, dada a sua natureza multidimensional (Huppert, 2017), estando estritamente relacionado com a saúde mental (SM) e pressupõe que o indivíduo deve envolver-se no seu dia-a-dia, com base nos seus objetivos e pontos fortes, e encontrar significado e

\section{INTRODUCTION}

The concept of wellbeing, although commonly used, is still an ambiguous term in the literature (Dodge et al., 2012; Pollard and Lee, 2003). It is defined from several perspectives, given its multidimensional nature (Huppert, 2017); it is strictly related to mental health $(\mathrm{MH})$ and presupposes that the individual must be engaged in his or her daily life based on his or her goals and strengths, as well as finding meaning and purpose in his or her occupation through the construction of personal identity 
propósito nas suas ocupações, através da construção de uma identidade pessoal e da manutenção de papéis socialmente valorizados (Keyes, 2005; Slade, 2010). Outros autores definemno como uma estrutura que equilibra recursos e desafios nos três principais domínios, o físico, psicológico e social (Department of Health \& Social Care, 2018; Dodge et al., 2012).

A literatura enfatiza a existência de duas perspetivas para conceptualizar o bem-estar: a abordagem hedónica, que o define como a procura pessoal do prazer e evasão à dor e sofrimento; e a abordagem eudemónica, que o define como o nível em que o indivíduo está totalmente funcional (Disabato et al., 2016; Ryan and Deci, 2001; Sheldon et al., 2019; The Children's Society, 2018). Para uma adequada avaliação do bem-estar, ambas as perspetivas devem ser consideradas, englobando a dimensão emocional e a funcionalidade (Disabato et al., 2016; Tamir and Gross, 2011).

O conceito de bem-estar engloba três grandes domínios - o emocional, o psicológico e o social - que operacionalizam o conceito de SM (Dodge et al., 2012; Keyes, 2002; 2005; 2007; National Institute for Clinical Excellence, 2009). O Modelo do Estado Completo de SM, identifica duas dimensões, no qual a SM está presente num continuum, de nenhuma/incompleta a completa, e o bem-estar encontra-se num outro continuum, que varia entre baixo e alto (Keyes, 2002; Slade, 2010). A presença de SM é descrita como flourishing e caracteriza-se por uma combinação de altos níveis de bem-estar emocional, psicológico e social e a ausência de psicopatologia (Keyes, 2002; 2005; Keyes et al., 2010). Por sua vez, indivíduos que se situem num estado de languishing possuem uma SM incompleta, com baixos níveis de bem-estar (Keyes, 2002; 2005; Keyes et al., 2010). Este modelo considera que indivíduos que se encontram no centro deste continuum possuem um estado de SM moderada (Keyes, 2002; 2005; Keyes et al., 2010).

No caso dos jovens, o bem-estar é influenciado por um conjunto de fatores, nomeadamente a preocupação com a sua aparência, a tomada de decisões, a gestão financeira e do tempo, o contexto familiar - relacionamentos familiares e habitação, o contexto escolar - relações entre os pares, desempenho escolar e comportamentos de bullying, a comunidade em que vivem - estado de saúde e segurança - e, consequentemente, a sociedade em geral (Matos, 2018; National Center Social Research, 2013; National Institute for Clinical Excellence, 2009; The Children's Society, 2018; UNICEF Office of Research, 2013). Pode-se, então, considerar que, se os fatores descritos tiverem um desenvolvimento negativo, podem contribuir para uma diminuição da SM o que, por sua vez, compromete o envolvimento do jovem nas ocupações, acabando por ter um impacto negativo no seu bem-estar e reforçar as desigualdades sociais (National Institute for Clinical Excellence, 2009; World Health Organization, 2013).

Através de uma perspetiva centrada no cliente, com base em ocupações significativas, o terapeuta ocupacional pode promover este envolvimento e participação dos indivíduos. A participação, que engloba o desempenho, é o que promove saúde, bem-estar e qualidade de vida (Pizzi and Richards, 2017). De acordo com a American Occupational Therapy Association (2014) a saúde e bem-estar e, consequentemente, a qualidade de vida e a justiça ocupacional são áreas de interesse e de and the maintenance of socially valued roles (Keyes, 2005; Slade, 2010). Other authors also define it as a structure that balances resources and challenges in the three main domains, the physical, psychological, and social (Department of Health \& Social Care, 2018; Dodge et al., 2012).

The literature emphasizes the existence of two perspectives to conceptualize wellbeing: the hedonic approach, which is defined as the personal search for pleasure and avoidance of pain and suffering, and the eudemonic approach, which is the level of the individual who is fully functional (Disabato et al., 2016; Ryan and Deci, 2001; Sheldon et al., 2019; The Children's Society, 2018). For an adequate assessment of wellbeing, both perspectives must be considered, as this requires an evaluation of the emotional dimension and functionality (Disabato et al., 2016; Tamir and Gross, 2011).

The concept of wellbeing includes three major domains, emotional, psychological, and social, that operationalize the concept of MH (Dodge et al., 2012; Keyes, 2002; 2005; 2007; National Institute for Clinical Excellence, 2009). The complete $\mathrm{MH}$ state model identifies two dimensions, in which $\mathrm{MH}$ is present in a continuum, from none/incomplete to complete, and wellbeing is found in another continuum, which varies between low and high (Keyes, 2002; Slade, 2010). The presence of MH is described as flourishing and is characterized by a combination of high levels of emotional, psychological, and social wellbeing and the absence of psychopathology (Keyes, 2002; 2005; Keyes et al., 2010). In turn, individuals who are in a languishing state have incomplete $\mathrm{MH}$, with low levels of wellbeing (Keyes, 2002; 2005; Keyes et al., 2010). This model considers that individuals who are at the centre of this continuum have a moderate state of MH (Keyes, 2002; 2005; Keyes et al., 2010).

The wellbeing of young people is influenced by several factors, namely, the concern with their appearance, decisionmaking, financial and time management, the family context, i.e., family relationships and housing, the school context, i.e., relationships between duos, school performance and bullying behaviours, the community in which they live, i.e., health status and safety, and, consequently, society in general (Matos, 2018; National Centre for Social Research, 2013; National Institute for Clinical Excellence, 2009; The Children's Society, 2018; UNICEF Office of Research, 2013). Therefore, it can be considered that the factors described contribute to a decrease in $\mathrm{MH}$, which, in turn, compromises the individual's engagement in his or her occupations, ultimately causing a negative impact on his or her wellbeing and reinforcing social inequalities (National Institute for Clinical Excellence, 2009; World Health Organization, 2013).

Through a client-centred perspective, based on meaningful occupations, the occupational therapist can promote this engagement and participation of individuals. Participation, which encompasses performance, is what promotes health, wellbeing, and quality of life (Pizzi and Richards, 2017). According to the American Occupational Therapy Association (2014), health and wellbeing and, consequently, quality of life and occupational justice are areas of interest and intervention for the profession. To establish strong intervention and prevention programs and to be a leader in this area, occupational therapists have to assess the needs of populations and intervene based on models that link occupation and participation with health 
intervenção para a profissão. Para estabelecer programas de intervenção e de prevenção sólidos, e ser um líder nesta área, os terapeutas ocupacionais precisam de avaliar as necessidades das populações e de intervir com base em modelos que liguem claramente a ocupação e a participação com a saúde, o bemestar, e a qualidade de vida de indivíduos, comunidades e populações (Pizzi and Richards, 2017).

As iniciativas de promoção de bem-estar descritas na literatura têm sido aplicadas, especialmente, em países onde a prevalência do nível de bem-estar da população jovem é inferior ao desejável (UNICEF Office of Research, 2013). Em Portugal, os estudos sobre a saúde dos jovens dificilmente perspetivam o bem-estar (Matos, 2018; Prazeres et al., 2005; UNICEF Office of Research, 2013; 2017), pelo que se torna pertinente, para fundamentar a prática da Terapia Ocupacional com estes jovens, saber qual o nível de bem-estar sentido e se esses valores se enquadram nos descritos para a restante população mundial. O objetivo do presente estudo é, então, descrever a prevalência do nível de bem-estar da população jovem, entre os 14 e os 18 anos, na Área Metropolitana do Porto.

\section{MATERIAL E MÉTODOS}

\subsection{PARTICIPANTES}

Desenhou-se um estudo observacional descritivo e de carácter transversal, de forma a avaliar os jovens que frequentavam seis escolas secundárias da Área Metropolitana do Porto, seleccionados por amostragem não probabilística por conveniência. Os participantes foram recrutados através de contactos institucionais a alunos de instituições de ensino secundário e superior da área metropolitana do Porto. Os investigadores delocaram-se presencialmente às instituições, dando os esclarecimentos necessários e assegurando o preenchimento individual do questionário por parte dos participantes que consentiram em participar no estudo. Definiu-se como critério de inclusão ter idades compreendidas entre os 14 e 18 anos, dado que em idades inferiores seria difícil de compreender o conteúdo das perguntas; e como critério de exclusão o ter problemas de comunicação ou cognitivos que pudessem comprometer a compreensão dos questionários.

\subsection{PROCEDIMENTOS}

A Comissão de Ética da Escola Superior de Saúde do Politécnico do Porto (ESS|P.Porto) aprovou o estudo (CE1232) e os pais assinaram o termo de consentimento informado, de acordo com a Declaração de Helsínquia (World Medical Association, 1999), permitindo a participação dos seus filhos. Todos os jovens responderam ao questionário durante as aulas, sendo os dados recolhidos entre fevereiro e maio de 2019.

\subsection{MÉTODO DE RECOLHA DE DADOS}

\section{Questionário Sociodemográfico}

Foram recolhidas variáveis dos participantes acerca da idade, sexo, estado civil, grau de escolaridade, cidade de residência, situação laboral, ser cuidador e conhecer indivíduos com problemas de SM. wellbeing, and the quality of life of individuals, communities, and populations (Pizzi and Richards, 2017).

The wellbeing promotion initiatives described in the literature have been applied, especially in countries where the prevalence of the youth population's level of wellbeing is lower than desirable (UNICEF Office of Research, 2013). In Portugal, studies about the health of young people hardly predict wellbeing (Matos, 2018; Prazeres et al., 2005; UNICEF Office of Research, 2013; 2017), so it becomes pertinent to support the practice of occupational therapy with these young people, to know what level of wellbeing is felt and to see if these values correspond to those described for the rest of the world population. Therefore, the purpose of this study is to describe the prevalence of the wellbeing level of young people between ages 14 and 18 in the metropolitan area of Porto.

\section{MATERIAL AND METHODS}

\subsection{PARTICIPANTS}

A descriptive, cross-sectional, and observational study was designed to assess young people who attended six secondary schools in the metropolitan area of Porto, selected by nonprobabilistic convenience sampling. Participants were recruited through institutional contacts with students from secondary and higher education institutions in the metropolitan area of Porto. The researchers visited the institutions in person, provided the necessary clarifications, and ensured the individual completion of the questionnaire by the participants who consented to participate in the study. It was defined as an inclusion criterion to be aged between 14 and 18 years, since at younger ages it would be difficult to understand the content of the questions, and as an exclusion criterion, having communication or cognitive problems that could compromise the understanding of the questionnaire.

\subsection{PROCEDURES}

The Ethics Committee of the Higher School of Health of the Polytechnic Institute of Porto (ESS|P. Porto) approved the study (CE1232), and the parents signed an informed consent form following the Declaration of Helsinki (World Medical Association, 1999), allowing their children to participate. All young people answered the questionnaire during classes, with data being collected from February to May 2019.

\subsection{DATA COLLECTION METHOD}

\section{Sociodemographic Questionnaire}

Variables were collected from the participants regarding age, sex, marital status, education level, city of residence, employment status, being a caregiver, and knowing someone with $\mathrm{MH}$ problems.

\section{Warwick-Edinburgh Mental Wellbeing Scale (WEMWS)}

The scale aims to measure the mental wellbeing of populations and groups over time (Figueiredo et al., 2019; Tennant et al., 2007). The 14-item scale addresses the hedonic and eudemonic aspects of $\mathrm{MH}$, including positive affect, satisfaction with interpersonal relationships, and positive functioning. The scale covers only positive aspects of $\mathrm{MH}$, and 


\section{Warwick-Edinburgh Mental Wellbeing Scale (WEMWS)}

A escala tem como objetivo medir o bem-estar mental de populações e grupos ao longo do tempo (Figueiredo et al., 2019; Tennant et al., 2007). É composta por 14 itens e aborda aspetos hedónicos e eudemónicos da SM, incluindo afeto positivo, satisfação com os relacionamentos interpessoais e funcionamento positivo. Abrange apenas aspetos positivos da SM e todos os itens são expressos de forma positiva. A consistência interna obtida pelos autores é de $\alpha=0.91$ (Tennant et al., 2007). Este instrumento foi validado para a população portuguesa, pelo Laboratório de Reabilitação Psicossocial (LabRP) da ESS|P.Porto, e o valor de consistência interna obtido foi de $a=0.91$ (Figueiredo et al., 2019).

Os indivíduos devem selecionar a opção que melhor descreve a sua experiência, relativamente a cada afirmação, nas duas últimas semanas, usando uma escala de Likert de 5 pontos ( $1=$ nunca a $5=$ sempre). A pontuação geral é calculada através da soma do valor atribuído a cada item, sendo a pontuação mínima possível de 14 e a máxima de 70 pontos. Quanto mais alta a pontuação, maior o nível de bem-estar mental (Figueiredo et al., 2019; Tennant et al., 2007).

\section{Pemberton Happiness Index (PHI)}

A escala mede os níveis de bem-estar em diferentes domínios, na população em geral (Hervás and Vázquez, 2013; Maia et al., 2019). A validação dos autores obteve uma consistência interna de $\alpha=0,89$ (Hervás and Vázquez, 2013). Este instrumento foi validado para a população portuguesa, pelo LabRP da ESS|P.Porto, tendo obtido um valor de consistência interna de $a=0.90$ (Maia et al., 2019).

Esta escala é composta por duas partes, em que a primeira consiste em 11 itens relacionados com o "bem-estar recordado", ou seja, as memórias passadas globais associadas ao bemestar, e cada item é avaliado numa escala Likert de 11 pontos ( $0=$ Discordo totalmente a $10=$ Concordo totalmente) (Hervás and Vázquez, 2013; Maia et al., 2019). Estes itens encontramse organizados em quatro dimensões: 1) Bem-estar global (itens 1 e 2); 2) Bem-estar eudemónico (itens 3 a 8); 3) Bemestar hedónico (itens 9 e 10); e 4) Bem-estar social (item 11). A segunda parte integra 10 itens relacionados com o "bem-estar experienciado", ou seja, relativo a eventos positivos (itens 1 , $3,5,7$ e 8) e negativos (itens $2,4,6,9$ e 10) que ocorreram no dia anterior, para aproximar a avaliação da experiência real e reduzir os enviesamentos presentes no relembrar de eventos passados. Nesta segunda parte, todos os 10 itens têm opções de resposta dicotómica (sim e não).

A pontuação da primeira parte é calculada a partir da média dos primeiros 11 itens, sendo o item 10 cotado com um score invertido, e pode variar entre 0 e 10 pontos. Os 10 itens da segunda parte do instrumento são convertidos numa única pontuação, que varia de 0 (nenhuma experiência positiva e 5 experiências negativas) a 10 pontos ( 5 experiências positivas e nenhuma experiência negativa). A soma das pontuações das duas partes produz um índice combinado de bem-estar, sendo que quanto mais alta a pontuação, melhor o nível de bem-estar (Hervás and Vázquez, 2013; Maia et al., 2019). all items are expressed positively. The internal consistency obtained by the authors is $a=0.91$ (Tennant et al., 2007). This instrument was validated for the Portuguese population by the Psychosocial Rehabilitation Laboratory (LabRP) of ESS|P. Porto, and the value of internal consistency obtained was $a=0.91$ (Figueiredo et al., 2019).

Individuals were told to select the option that best described their experience for each statement in the past two weeks, using a 5 -point Likert scale ( $1=$ never to $5=$ =always). The overall score is calculated by adding the scores for each item, with the minimum possible score being 14 and the maximum score being 70 points. The higher the score on the instrument is, the higher the level of mental wellbeing (Figueiredo et al., 2019; Tennant et al., 2007).

\section{Pemberton Happiness Index (PHI)}

The scale measures levels of wellbeing in different domains in the general population (Hervás and Vázquez, 2013; Maia et al., 2019). The authors' validation obtained an internal consistency of $a=0.89$ (Hervás and Vázquez, 2013). This instrument was validated for the Portuguese population by the LabRP of ESS|P. Porto, and the value of internal consistency obtained was $\mathrm{a}=0.90$ (Maia et al., 2019).

This scale consists of two parts. The first consists of 11 items related to "recalled wellbeing", that is, the global past memories associated with wellbeing, and each item is assessed on a 10-point Likert scale ( $0=$ strongly disagree to $10=$ strongly agree) (Hervás and Vázquez, 2013; Maia et al., 2019). These items are organized into four dimensions: 1) global wellbeing (Items 1 and 2); 2) eudemonic wellbeing (Items 3 to 8); 3) hedonic wellbeing (Items 9 and 10); and 4) social wellbeing (Item 11). The second part includes 10 items related to "experienced wellbeing", that is, related to positive (Items 1, 3, 5, 7, and 8) and negative events (Items 2, 4, 6, 9, and 10) that occurred the day before, to bring the evaluation closer to the real experience and to reduce the biases present in remembering past memories. All 10 items have dichotomous answer options (yes/no).

The score of the first part is calculated with the average of the first 11 items, with Item 10 quoted with an inverted score, and can vary from 0 to 10 points. The 10 items in the second part of the instrument are converted into a single score, which ranges from 0 (no positive experiences and five negative experiences) to 10 (five positive experiences and no negative experiences). The sum of the corresponding scores produces a combined index of wellbeing. The higher the score is, the better the level of wellbeing (Hervás and Vázquez, 2013; Maia et al., 2019).

\subsection{STATISTICAL ANALYSIS}

The statistical analysis of the collected data was performed using the Statistical Package for the Social Sciences (SPSS) version 25.0 for Windows. Descriptive statistics were used to characterize the sample and to represent data related to wellbeing. Student's t test for independent samples and oneway ANOVA with Bonferroni correction were used to assess differences in wellbeing according to sociodemographic variables (Marôco, 2018).

To understand the possible predictors of wellbeing, a multiple linear regression was applied, with the selection 


\subsection{ANÁLISE ESTATÍSTICA}

A análise estatística dos dados recolhidos foi efetuada utilizando o programa Statistical Package for the Social Sciences (SPSS) versão 25.0 para Windows. Utilizou-se estatística descritiva para caracterizar a amostra e para representar os dados relativos ao bem-estar. Os testes $t$ de Student para amostras independentes e ANOVA a um fator com correção de Bonferroni foram utilizadas para averiguar as diferenças de bem-estar de acordo com as variáveis sociodemográficas (Marôco, 2018).

De forma a perceber os possíveis preditores de bem-estar, foi utilizada uma regressão linear múltipla, com a seleção do modelo Stepwise para obter um modelo parcimonioso que permitisse predizer os níveis de bem-estar em função das variáveis sociodemográficas. Optou-se por realizar a regressão linear múltipla apenas para o $\mathrm{PHI}$, uma vez que era a única escala que seguia todos os pressupostos (Marôco, 2018).

\section{RESULTADOS}

A amostra (Tabela 1) foi constituída por 847 jovens (sendo $61,0 \%$ do sexo feminino), com idades entre os 14 e 18 anos (média 16,4 $\pm 1,2$ anos) e com residência maioritariamente nos concelhos do Porto (33,3\%) e Vila Nova de Gaia (29,0\%). Do total da amostra, $79,5 \%$ jovens possuem o $3^{\circ}$ ciclo, $2,8 \%$ referem ser cuidadores de um indivíduo com algum problema de saúde e $46,0 \%$ já conheceram alguém com problemas de SM.

Relativamente ao nível de bem-estar apresentado pelos jovens, a Tabela 2 mostra os resultados obtidos nos dois instrumentos usados, com valores médios de 49,23 $( \pm 10,02)$ na WEMWS e de 7,22 $( \pm 1,60)$ no PHI. Existem diferenças estatisticamente significativas na WEMWS e no PHI de acordo com o sexo, sendo o sexo masculino o que apresenta um melhor nível de bem-estar $(p<0,001)$; os jovens que não conhecem ninguém com problemas de SM apresentam maior bem-estar que aqueles que conhecem ( $p<0,001)$; e de acordo com o local de residência, com os que residem na cidade de Matosinhos a apresentarem maior bem-estar $\left(p_{\text {WEMWS }}=0,045 ; p_{P H I}=0,011\right)$. É ainda possível observar que os jovens do $2^{\circ}$ ciclo apresentam um bem-estar superior aos do $3^{\circ}$ ciclo e ensino secundário e os do $3^{\circ}$ ciclo, um bem-estar superior aos do secundário, quando medido pela WEMWS ( $p_{\text {WEMWS }}=0,031$ ).

Relativamente aos preditores de bem-estar (Tabela 3), a análise do modelo Stepwise resultante da regressão linear múltipla mostra que, quando medido com o $\mathrm{PHI}$, são preditores do bem-estar na presente amostra ser do sexo masculino $\left(\beta_{\text {sexo }}\right.$ feminino $=-0,567 ; p<0,001)$, não conhecer pessoas com problemas de SM ( $\left.\beta_{\text {conhecer }}=-0,340 ; p=0,001\right)$ e um grau de escolaridade mais baixo $\left(\beta_{\text {escolaridade mais alta }}=0,253 ; p=0,024\right)$. O modelo 3 , que inclui as três variáveis descritas, é o que melhor explica os valores de bem-estar, com coeficiente de correlação, $R=0,229$ e coeficiente de determinação, $R^{2}=0,052$. Assim, ser do sexo masculino, ter uma menor escolaridade e não conhecer ninguém com problemas de SM parecem funcionar como fatores protetores para a probabilidade de apresentar bem-estar, quando medido pelo $\mathrm{PHI}$. of the stepwise model to obtain a parsimonious model that allowed us to predict the levels of wellbeing according to sociodemographic variables. Multiple linear regression was performed only for the $\mathrm{PHI}$, since it was the only scale that followed all the assumptions (Marôco, 2018).

\section{RESULTS}

The sample (Table 1) consisted of 847 young people (of whom $61.0 \%$ were female), aged between 14 and 18 years old (mean 16.4 \pm 1.2 years) and mostly residing in the cities of Porto (33.3\%) and Vila Nova de Gaia (29.0\%). Of the total sample, $79.5 \%$ of young people had the third cycle, $2.8 \%$ reported being caregivers of an individual with a health problem, and $46.0 \%$ had already known someone with $\mathrm{MH}$ problems.

Regarding the level of wellbeing displayed by young people, Table 2 shows the results obtained in the two instruments used for this purpose, whose average values were $49.23( \pm 10.02)$ in WEMWS and $7.22( \pm 1.60)$ in PHI. There were statistically significant differences in WEMWBS and PHI according to sex, with young males showing a better level of wellbeing $(p<0.001)$; young people who did not know anyone with $\mathrm{MH}$ problems had greater wellbeing than those who did know someone with $\mathrm{MH}$ problems $(p<0.001)$; and according to the cities of residence, they had greater wellbeing in the city of Matosinhos ( $p_{\text {WEMWS }}=0.045 ; p_{\text {PHI }}=0.011$ ). It is also possible to observe that young people in the second cycle had a higher level of wellbeing than those in the third cycle and secondary education, and those in the third cycle had a higher level of wellbeing than those in secondary education when measured by the WEMWS ( $p_{\text {WEMWS }}=0.031$ ).

Regarding wellbeing predictors (Table 3 ), the analysis of the stepwise model resulting from the multiple linear regression shows that when measured with the $\mathrm{PHI}$, being male $\left(\beta_{\text {female }}=-0.567 ; \mathrm{p}<0.001\right)$, not knowing people with $\mathrm{MH}$ problems $\left(\beta_{\text {knowing }}=-0.340 ; p=0.001\right)$, and having a lower level of education $\left(\beta_{\text {higher education }}=0.253 ; p=0.024\right)$ were predictors of wellbeing. Model 3, which includes the three variables described, best explains the wellbeing values, with a correlation coefficient of $R=0.229$ and a determination coefficient of $R^{2}=0.052$. Thus, being male, having less education, and not knowing anyone with $\mathrm{MH}$ problems seem to work as protective factors for the probability of presenting wellbeing when measured by the $\mathrm{PHI}$. 
Tabela/Table 1: Caracterização da amostra relativamente a dados sociodemográficos e ao bem-estar/Sample characterization of sociodemographic data and wellbeing

\begin{tabular}{|c|c|c|}
\hline & Média/Mean (dp) & $\begin{array}{l}\text { Mínimo - Máximo } \\
\text { Minimum - Maximum }\end{array}$ \\
\hline Idade/Age & $16,4( \pm 1,2)$ & $14-18$ \\
\hline & & $\mathrm{N}(\%)$ \\
\hline Sexo/Sex & $\begin{array}{l}\text { Masculino/Male } \\
\text { Feminino/Female }\end{array}$ & $\begin{array}{l}330(39,0) \\
517(61,0)\end{array}$ \\
\hline Grau de escolaridade/Education level & $\begin{array}{c}2^{\circ} \mathrm{ciclo} / 2^{\text {nd }} \mathrm{cycle} \\
3^{\circ} \mathrm{ciclo} / 3^{\mathrm{rd}} \mathrm{cycle} \\
\text { Secundário/Secondary education }\end{array}$ & $\begin{array}{c}46(5,4) \\
673(79,5) \\
128(15,1)\end{array}$ \\
\hline Residência/City of residence* & $\begin{array}{c}\text { Porto } \\
\text { Vila Nova de Gaia } \\
\text { Gondomar + Valongo } \\
\text { Matosinhos } \\
\text { Maia } \\
\text { Paredes } \\
\text { Santa Maria da Feira } \\
\text { Santo Tirso + Guimarães } \\
\text { Vila do Conde + Viana do Castelo }\end{array}$ & $\begin{array}{c}282(33,3) \\
246(29) \\
190(22,4) \\
63(7,4) \\
17(2,0) \\
12(1,4) \\
12(1,4) \\
11(1,3) \\
8(0,9)\end{array}$ \\
\hline $\begin{array}{l}\text { Ser cuidador de alguém com problemas de saúde/ Being caregiver of an } \\
\text { individual with a health problem** }\end{array}$ & $\begin{array}{l}\mathrm{Sim} / \text { Yes } \\
\text { Não/No }\end{array}$ & $\begin{array}{c}24(2,8) \\
777(91,7)\end{array}$ \\
\hline $\begin{array}{l}\text { Conhecer alguém com problemas de SM/ Knowing someone with MH } \\
\text { problems** }\end{array}$ & $\begin{array}{l}\text { Sim/Yes } \\
\text { Não/No }\end{array}$ & $\begin{array}{l}391(46,2) \\
410(48,4)\end{array}$ \\
\hline
\end{tabular}

Tabela/Table 2: Diferenças entre sexos, ser cuidador, conhecer alguém com problemas de SM, graus de escolaridade e residência relativamente ao bem-estar/Differences between sexes, being a caregiver, knowing someone with $\mathrm{MH}$ problems, level of education, and city of residence regarding wellbeing

\begin{tabular}{|c|c|c|c|c|c|}
\hline & & $\begin{array}{c}\text { WEMWS } \\
\text { Média/Mean (dp) }\end{array}$ & Valor/Value $\mathbf{p}$ & $\begin{array}{c}\text { PHI } \\
\text { Média/Mean (dp) }\end{array}$ & Valor/Value $\mathbf{p}$ \\
\hline & & $49,23(10,02)$ & & $7,22(1,60)$ & \\
\hline \multirow{2}{*}{ Sexo/Sex } & Masculino/Male & $52,40(9,37)$ & \multirow{2}{*}{$<0,001^{*}$} & $7,51(1,48)$ & \multirow{2}{*}{$<0,001^{*}$} \\
\hline & Feminino/Female & $47,10(9,31)$ & & $7,01(1,58)$ & \\
\hline \multirow{2}{*}{ Ser cuidador/Being a caregiver } & Sim/Yes & $50,46(9,02)$ & \multirow{2}{*}{$0,471^{*}$} & $7,24(1,34)$ & \multirow{2}{*}{$0,877^{*}$} \\
\hline & Não/No & $49,08(9,70)$ & & $7,20(1,57)$ & \\
\hline \multirow{2}{*}{$\begin{array}{l}\text { Conhecer alguém com problemas de SM/ } \\
\text { Knowing someone with MH problems }\end{array}$} & Sim/Yes & $47,60(9,96)$ & \multirow{2}{*}{$<0,001^{*}$} & $6,99(1,68)$ & \multirow{2}{*}{$<0,001^{*}$} \\
\hline & Não/No & $50,56(9,18)$ & & $7,40(1,42)$ & \\
\hline \multirow{3}{*}{ Grau de escolaridade/Education level } & $2^{\circ}$ ciclo/2nd cycle & $50,80(12,75)$ & \multirow{3}{*}{$0,031 * *$} & $7,05(1,99)$ & \multirow{3}{*}{$0,292^{* *}$} \\
\hline & $3^{\circ}$ ciclo/3rd cycle & $49,41(9,63)$ & & $7,17(1,58)$ & \\
\hline & $\begin{array}{l}\text { Secundário/Secondary } \\
\text { education }\end{array}$ & $47,13(8,38)$ & & $7,40(1,28)$ & \\
\hline \multirow{9}{*}{ Cidade de Residência/City of residence* } & Porto & $49,45(10,05)$ & \multirow{9}{*}{$0,045^{* *}$} & $7,32(1,49)$ & \multirow{9}{*}{$0,011^{* *}$} \\
\hline & Vila Nova de Gaia & $49,44(9,34)$ & & $7,19(1,56)$ & \\
\hline & Gondomar + Valongo & $47,95(9,66)$ & & $6,92(1,64)$ & \\
\hline & Matosinhos & $53,24(9,90)$ & & $7,84(1,53)$ & \\
\hline & Maia & $50,35(9,55)$ & & $7,71(1,62)$ & \\
\hline & Paredes & $48,67(12,38)$ & & $7,19(2,15)$ & \\
\hline & Santa Maria da Feira & $47,75(7,69)$ & & $6,77(1,35)$ & \\
\hline & $\begin{array}{l}\text { Vila do Conde + Viana do } \\
\text { Castelo }\end{array}$ & $49,88(5,52)$ & & $7,86(1,03)$ & \\
\hline & Santo Tirso + Guimarães & $46,55(8,09)$ & & $7,54(1,22)$ & \\
\hline
\end{tabular}


Tabela/Table 3: Regressão linear múltipla das variáveis sexo, grau de escolaridade e conhecer alguém com problemas de SM como preditores do bem-estar/Multiple linear regression of the variables sex, education level, and knowing someone with $\mathrm{MH}$ problems as predictors of wellbeing.

\begin{tabular}{|c|c|c|c|c|c|c|}
\hline & \multirow{2}{*}{ Modelo/Model a } & \multicolumn{2}{|c|}{$\begin{array}{l}\text { Coeficientes não padronizados/ } \\
\text { Nonstandard coefficients }\end{array}$} & \multirow{2}{*}{ Valor/Value $p$} & \multicolumn{2}{|c|}{$\begin{array}{l}\text { 95\% Intervalo de Confiança/Confidence } \\
\text { Interval para/for B }\end{array}$} \\
\hline & & B & Erro/Error & & $\begin{array}{l}\text { Limite inferior/ } \\
\text { Inferior limit }\end{array}$ & $\begin{array}{l}\text { Limite superior/ } \\
\text { Superior limit }\end{array}$ \\
\hline \multirow{2}{*}{1} & (Constante/Constant) & 8,151 & 0,178 & $<0,001$ & 7,802 & 8,500 \\
\hline & Sexo/Sex & $-0,540$ & 0,105 & $<0,001$ & $-0,746$ & $-0,334$ \\
\hline \multirow{3}{*}{2} & (Constante/Constant) & 8,299 & 0,182 & $<0,001$ & 7,941 & 8,657 \\
\hline & Sexo/Sex & $-0,532$ & 0,104 & $<0,001$ & $-0,737$ & $-0,327$ \\
\hline & $\begin{array}{l}\text { Conhecer alguém com problemas de SM/Knowing } \\
\text { someone with MH problems }\end{array}$ & $-0,333$ & 0,101 & 0,001 & $-0,532$ & $-0,134$ \\
\hline \multirow{4}{*}{3} & (Constante/Constant) & 7,573 & 0,369 & $<0,001$ & 6,848 & 8,299 \\
\hline & Sexo/Sex & $-0,567$ & 0,105 & $<0,001$ & $-0,774$ & $-0,360$ \\
\hline & $\begin{array}{l}\text { Conhecer alguém com problemas de } \mathrm{SM} / \text { Knowing } \\
\text { someone with } \mathrm{MH} \text { problems }\end{array}$ & $-0,340$ & 0,101 & 0,001 & $-0,538$ & $-0,141$ \\
\hline & Grau de Escolaridade/Education level & 0,253 & 0,112 & 0,024 & 0,033 & 0,473 \\
\hline
\end{tabular}

\section{DISCUSSÃO}

No que se refere à caracterização do nível de bem-estar da população jovem, apesar das escalas não possuírem pontos de corte, é possível dizer que a amostra apresenta valores de bem-estar situados acima das pontuações médias de ambas as escalas, indicando uma tendência para um moderado bemestar. Estes dados vão ao encontro do relatório de bem-estar da UNICEF, onde a população jovem portuguesa se encontra na $15^{a}$ posição, num total de 29 países (UNICEF Office of Research, 2013). A Holanda é o único país classificado nos primeiros lugares do ranking em todas as dimensões do bemestar infantil, sendo que os países nórdicos - Finlândia, Islândia, Noruega e Suécia - ficam logo abaixo da Holanda (UNICEF Office of Research, 2013). Estes níveis de bem-estar traduzem, segundo um estudo de Ringdal e colaboradores (2018) com jovens noruegueses, uma pontuação média na WEMWS de 50,2 $( \pm 9,8)$, sendo esta pontuação ligeiramente superior aos valores obtidos no presente estudo sobre os jovens portugueses, com valores médios de 49,23 $( \pm 10,02)$. Segundo Hervás e Vázquez (2013), a população sueca apresenta uma pontuação média no $\mathrm{PHI}$ de $6.76( \pm 1.97)$ que, apesar de estar aplicada à população em geral, é inferior à obtida nos jovens deste estudo. Assim, podemos dizer que os níveis de bem-estar obtidos são, efetivamente, tradutores de, pelo menos, um moderado bemestar.

Tal como se verifica na literatura, também no presente estudo se obteve uma diferença significativa entre os níveis de bem-estar medido pelas duas escalas e a variável sexo, com o sexo masculino a apresentar um melhor nível de bem-estar (D'Agostino et al., 2018; Kaye-Tzadok et al., 2017; Matos et al., 2010; Mostafa and Ploubidis, 2017; National Center Social Research, 2013; The Children's Society, 2018). No sexo feminino, são referidas mais queixas subjetivas de saúde - somáticas e psicológicas - que provocam desconforto e mais sintomas depressivos, que se intensificam com a idade (Currie et al., 2012), especialmente a partir do ensino secundário, conduzindo, consequentemente, a uma menor perceção de bem-estar (Haugland et al., 2001; Levin et al., 2009). Aparentemente, estas perceções são causadas por fatores como o uso imaturo do mundo digital, onde as redes sociais assumem um elevado

\section{DISCUSSION}

Regarding the description of the level of wellbeing of the young population, although the scales do not have cutoff points, it is possible to say that the sample presents levels of wellbeing higher than the average scores, which indicate a trend towards moderate wellbeing. These data are in line with the 2013 UNICEF wellbeing report, where the young Portuguese population was in the $15^{\text {th }}$ position, among a total of 29 countries (UNICEF Office of Research, 2013). The Netherlands was the only country ranked at the top of the rankings in all dimensions of child wellbeing, with four Nordic countries, i.e., Finland, Iceland, Norway, and Sweden, trailing just below the Netherlands (UNICEF Office of Research, 2013). These levels of wellbeing translate, according to a study by Ringdal et al. (2018) with young Norwegians, an average WEMWBS score of 50.2 $( \pm 9.8)$; this score is slightly higher than the values obtained in the present study on Portuguese youth, with mean values of 49.23 ( \pm 10.02$)$. According to Hervás and Vázquez (2013), the Swedish population has an average PHI score of $6.76( \pm 1.97)$, which, despite being applied to the general population, is lower than that obtained among the young people in this study. Thus, we can say that the levels of wellbeing obtained are, effectively, translators of at least moderate wellbeing.

As seen in the literature, and also in the present study, a significant relationship was obtained between the two scales and the sex variable, with the male sex presenting a better level of wellbeing (D'Agostino et al., 2018; Kaye-Tzadok et al., 2017; Matos et al., 2010; Mostafa and Ploubidis, 2017; National Centre for Social Research, 2013; The Children's Society, 2018). In females, more subjective health complaints, somatic and psychological, are reported that cause discomfort and more depressive symptoms, which intensify with age (Currie et al., 2012), especially from secondary school, consequently leading to a lower perception of wellbeing (Haugland et al., 2001; Levin et al., 2009). These perceptions are caused by several factors, such as the immature use of the digital world, where social networks have a high impact on body image, self-confidence, satisfaction with life, and helplessness (Savoye et al., 2015), and the awareness of gender stereotypes between friendship groups, where for women the importance of looking good, 
impacto na imagem corporal, autoconfiança, satisfação com a vida e desamparo (Savoye et al., 2015) e a consciência dos estereótipos de género entre grupos de amizade onde, para o sexo feminino, é enfatizada a importância de ter uma boa aparência, ser carinhosa e ter boas roupas, enquanto que para o sexo masculino, é destacada a importância de ter força física e ser engraçado. A consciência destes estereótipos contribui para um menor bem-estar dos jovens que consideram não cumprir o esperado para corresponder às expectativas impostas pela sociedade (Lindsey, 2015; Mmari et al., 2017; The Children's Society, 2018). Estes fatores podem levá-los a experimentar o insucesso, privá-los de se envolverem em ocupações significativas e induzir frustração e a ansiedade, que pode traduzir-se num declínio no seu bem-estar. A manutenção de uma sociedade estereotipada pelo género, com um maior impacto negativo ao nível do bem-estar no sexo feminino, levanta a necessidade da sociedade rever esta compreensão sobre as mulheres na procura de uma sociedade mais igualitária (Gómez-Baya et al., 2018; Muñoz et al., 2016; Muñoz et al., 2008).

Neste estudo sugere-se ainda uma relação significativa entre a WEMWS e a variável grau de escolaridade, indicando que os jovens com escolaridade mais baixa apresentam um maior bem-estar. Estes resultados são, embora indiretamente, apoiados pela literatura, onde Keyes e colaboradores (2010) referem uma tendência para uma descida do estado de flourishing nos indivíduos com maior escolaridade. Apesar de flourishing e bem-estar serem conceitos diferentes, eles podem ser comparáveis na medida em que o flourishing é um estado que abrange o alcance e manutenção de várias dimensões necessárias para despoletar uma sensação final de bemestar (Goodman et al., 2018; Seligman, 2012). Esta perspetiva é corroborada pelos estudos de Matos e colaboradores (2010), que verificaram que jovens a frequentar o ensino secundário possuem um menor estado de flourishing do que os do $2^{\circ}$ e $3^{\circ}$ ciclos. Keyes (2012) encontrou uma prevalência de flourishing maior (49\%) no ensino básico relativamente ao ensino secundário (40\%) e Ferreira (2015) descreveu um maior bem-estar emocional nos indivíduos que completaram o ensino básico, relativamente aos que completaram o ensino secundário, e um maior estado de flourishing relativamente aos que completaram o ensino superior.

Uma explicação parcial para esta diminuição do bem-estar por parte dos indivíduos com maior grau de escolaridade pode estar associada ao período de transição para a vida adulta, no qual se verifica um aumento da exigência, tanto no meio familiar como na sociedade, a separação em relação aos pais, o surgimento de novos papéis, a construção da autonomia e a diminuição das atividades de lazer em detrimento do trabalho (Ferreira, 2015; The Children's Society, 2018). No entanto, esta é uma explicação que apenas justifica o menor bem-estar nos jovens em transição para a idade adulta e não nas faixas etárias mais novas.

Os jovens que residem na cidade de Matosinhos apresentam maior bem-estar comparativamente ao conjunto das cidades de Gondomar e Valongo. Apesar de não haver, até onde os autores têm conhecimento, quaisquer dados que justifiquem claramente estes resultados, a literatura destaca que um baixo nível socioeconómico é um dos fatores que está, muitas vezes, associado a um menor bem-estar nos jovens being affectionate, and having good clothes is emphasized, whilst for men, the importance of having physical strength and being funny is emphasized. The awareness of these stereotypes contributes to the lower wellbeing of young people who consider that they do not fulfil what is expected to meet the expectations imposed by society (Lindsey, 2015; Mmari et al., 2017; The Children's Society, 2018). These factors can cause them to experience failure, deprive them of engaging in meaningful occupations, and induce frustration and anxiety, which can translate into a decline in their wellbeing. The maintenance of a gender-stereotyped society, with a greater negative impact on the wellbeing of women, raises the need for society to review this understanding of women in the search for a more egalitarian society (Gómez-Baya et al., 2018; Muñoz et al., 2016; Muñoz et al., 2008).

In this study, there also was a significant relationship between WEMWBS and the level of education variable, indicating that young people with lower education have greater wellbeing. These results are, albeit indirectly, supported by the literature, where Keyes et al. (2010) report a tendency for a decline in the flourishing status of individuals with higher education levels. Although flourishing and wellbeing are different concepts, they can be comparable in that flourishing is a state that encompasses the reach and maintenance of the various dimensions necessary to trigger a final feeling of wellbeing (Goodman et al., 2018; Seligman, 2012). This perspective is supported by the studies of Matos et al. (2010), who found that young people attending secondary education have a lower state of flourishing than those in the second and third cycles. Keyes (2012) found a higher prevalence of flourishing (49\%) in basic education compared to secondary education (40\%), and Ferreira (2015) described better emotional wellbeing in individuals who completed basic education compared to those who completed secondary education, and a greater state of flourishing compared to those who completed higher education.

A partial explanation for this decrease in wellbeing by individuals with a higher level of education may be associated with the transition to adulthood, in which there is increased demand, both in the family and in society, for separation from parents, the emergence of new roles, the construction of autonomy, and the reduction of leisure activities to the detriment of work (Ferreira, 2015; The Children's Society, 2018). However, this is an explanation that justifies the lower wellbeing in young people in transition to adulthood and not in the younger age groups.

Young people who live in the city of Matosinhos present greater wellbeing compared to those in the set of cities of Gondomar and Valongo. Although there are not, as far as the authors are aware, data that justify these results, the literature highlights that a low socioeconomic level is one of the factors that is often associated with lower wellbeing in young people (National Centre for Social Research, 2013; National Institute for Clinical Excellence, 2009; Pollard and Lee, 2003; The Children's Society, 2018). Knowing that the municipalities of Gondomar and Valongo have a relatively low socioeconomic level, occupying the 105th and 67th positions in the national ranking, while the municipality of Matosinhos has a higher socioeconomic level, placing itself in the ninth position, that is, 
(National Center Social Research, 2013; National Institute for Clinical Excellence, 2009; Pollard and Lee, 2003; The Children's Society, 2018). Sabendo que os municípios de Gondomar e Valongo apresentam um relativo baixo nível socioeconómico, ocupando as $105^{\mathrm{a}}$ e $67^{\mathrm{a}}$ posições no ranking nacional, enquanto o município de Matosinhos apresenta um maior nível socioeconómico, posicionando-se na $9^{a}$ posição, ou seja, bem acima da média nacional, podem justificar o menor bem-estar encontrado (Fundação Francisco Manuel dos Santos (FFMS), 2017).

Neste estudo, o facto de conhecer alguém com problemas de SM surgiu associado a valores de bem-estar inferiores. $\mathrm{O}$ contacto dos jovens com indivíduos que possuem problemas de SM pode ocorrer nos contextos familiar e social e ter um impacto negativo no bem-estar (Guedes, 2011; Helena, 2017; Masten and Reed, 2002). Jovens filhos de pais com doença mental têm maior probabilidade de desenvolverem problemas cognitivos, comportamentais e emocionais, o que pode comprometer o seu desempenho escolar e as suas relações sociais (Helena, 2017; Masten and Reed, 2002). Pode também gerar na família um sentimento de impotência (Gomes, 2014) e consequente diminuição do bem-estar.

O facto de, na presente amostra, não se terem encontrado diferenças no bem-estar relativamente a ser ou não cuidador de alguém com problemas de SM contraria a maioria dos estudos sobre o tema (Joseph et al., 2012; Local Government Association, 2018; The Children's Society, 2019). Estes referem as dificuldades dos jovens cuidadores em conseguirem atender às suas necessidades e desejos, pela sobrecarga que sofrem pelo papel de cuidador, e dificuldade em gerir os seus problemas sozinhos, sem orientação ou suporte emocional e social (The Children's Society, 2019; The Children's Society, 2017), o que conduz a um menor bem-estar. No entanto, neste estudo verificou-se uma tendência para haver um maior bem-estar em quem é cuidador. Apesar dos indivíduos da nossa amostra se identificarem com o papel de cuidador informal, devido à sua idade, entre os 14 e 18 anos, é possível que o seu grau de envolvimento seja de nível mais secundário, prestando cuidados complementares menos exigentes, de menor sobrecarga e, normalmente, em número mais reduzido, em comparação com um cuidador principal, que detém a total ou maior parte da responsabilidade pelos cuidados prestados ao familiar no domicílio (The Children's Society, 2017).

O presente estudo apresenta algumas limitações, como a utilização de questionário de autopreenchimento, pois a forma de interpretar conceitos mais subjetivos, como o do bem-estar, SM e ser cuidador informal, por parte de alguns participantes desta faixa etária, poderão ter influenciado os resultados.

Em investigações futuras considera-se importante analisar a diferença de bem-estar dos jovens portugueses sem qualquer patologia com outros jovens com problemas de SM ou com uma condição física incapacitante, nos contextos escolar e social, e investigar o impacto destas condições nos níveis de bem-estar. Indivíduos com incapacidades são alvo de preconceito e estigma social, o que, aliado à frustração e às barreiras com que se deparam diariamente, tem um impacto negativo e significativo no bem-estar psicológico e emocional e no seu desempenho ocupacional, vivendo, na maioria da vezes, well above the national average, may justify the lower wellbeing found (Fundação Francisco Manuel dos Santos (FFMS), 2017).

In this study, knowing someone with $\mathrm{MH}$ problems was associated with lower wellbeing values. The contact of young people with individuals who have $\mathrm{MH}$ problems can occur in the family and social contexts and have a negative impact on wellbeing (Guedes, 2011; Helena, 2017; Masten and Reed, 2002). Young children of parents with mental illness are more likely to develop cognitive, behavioural, and emotional problems, which can compromise their school performance and social relationships (Helena, 2017; Masten and Reed, 2002). It also can generate a feeling of powerlessness in the family (Gomes, 2014) and a consequent decrease in wellbeing.

The fact that, in this sample, there were no differences in wellbeing regarding being or not being a caregiver of someone with $\mathrm{MH}$ problems contradicts most studies on the subject (Joseph et al., 2012; Local Government Association, 2018; The Children's Society, 2019). These refer to the difficulties of young caregivers in being able to meet their needs and desires, the burden they suffer for the role of caregiver, and the difficulty in managing their problems alone, without guidance or emotional and social support (The Children's Society, 2019; The Children's Society, 2017), which leads to less wellbeing. However, in this study, there was a trend towards greater wellbeing in caregivers. Although the individuals in our sample identify with the role of informal caregiver, due to their age, between 14 and 18 years old, their level of involvement may be of a more secondary level, providing complementary care that is less demanding, less burdensome, and, usually, in a smaller amount, compared to the main caregiver, who holds all or most of the responsibility for the care provided to the family member at home (The Children's Society, 2017).

The present study has some limitations, such as the use of a self-administered questionnaire, because the way of interpreting more subjective concepts, such as wellbeing, $\mathrm{MH}$, and being an informal caregiver, by some participants in this age group may have influenced the results.

In future research, it is considered important to analyse the difference in wellbeing of young Portuguese people without any pathology with other young people with $\mathrm{MH}$ problems or with a disabling physical condition, in school and social contexts, and to investigate the impact of these conditions on levels of wellbeing. People with disabilities are commonly the target of prejudice and social stigma, which, combined with frustration and the barriers they face daily, has a negative and significant impact on psychological and emotional wellbeing and their occupational performance, as they live most of the time in occupational deprivation (Corrigan, 2004)

There is, of course, an injustice whenever people's occupational rights are violated and whenever opportunities are unfairly restricted. Occupational therapists thus have a moral and professional duty to work to create equitable opportunities for all people to improve their wellbeing through their occupation (Hammell, 2017).

\section{CONCLUSION}

In this study, it was possible to characterize the level of wellbeing of the young population, between 14 and 18 years 
em privação ocupacional (Corrigan, 2004).

É evidente que existe uma injustiça sempre que os direitos ocupacionais das pessoas são violados e sempre que as oportunidades são injustamente restringidas. Os terapeutas ocupacionais têm, assim, o dever moral e profissional de trabalhar a fim de criar oportunidades equitativas para todas as pessoas para melhorar o seu bem-estar através da sua ocupação (Hammell, 2017).

\section{CONCLUSÕES}

Neste estudo, foi possível descrever a prevalência do nível de bem-estar da população jovem, entre os 14 e os 18 anos, na Área Metropolitana do Porto. Aferiu-se que os jovens do sexo masculino, que não conhecem indivíduos com problemas de SM e com menor grau de escolaridade percecionam maior bem-estar. Nas restantes variáveis em estudo foi possível constatar diferenças nos níveis de bem-estar, em particular ser jovem cuidador e residir nos municípios com maior poder de compra per capita, parecendo estes fatores contribuir para maiores níveis de bem-estar.

O bem-estar constitui um elemento importante na vida do ser humano, oferecendo-lhe uma sensação de plenitude, felicidade e satisfação com a vida. A sensação de bem-estar parece estar intimamente relacionada com a participação prazerosa dos jovens nas ocupações que são significativas e com a satisfação com a sua vida. Neste sentido, os terapeutas ocupacionais, devem estar atentos ao que o indivíduo realmente valoriza e considera ser mais benéfico para si, enquanto objetivo a alcançar, uma vez que o bem-estar apenas poderá ser alcançado se o indivíduo se sentir em plenitude consigo próprio, se a sua participação ocupacional for ao encontro dos padrões por si definidos e se sentir satisfeito com a sua vida. Esta compreensão pode ter contribuído com mais um passo para o desenvolvimento de programas de intervenção direcionados aos jovens e que constituam um complemento importante para a prevenção de problemas de SM e, consequentemente, para a melhoria da saúde e bem-estar.

\section{CONTRIBUIÇÕES AUTORAIS}

Conceptualização, B.C., A.M. e M.T.; metodologia, B.C., M.T. e V.S.; software, B.C. e M.T.; validação, todos os autores; análise formal, B.C. e M.T.; investigação, B.C., M.T. e V.S.; redação - preparação do draft original, B.C. e M.T.; redação - revisão e edição, V.S e A.M. Todos os autores leram e concordaram com a versão publicada do manuscrito.

\section{REFERÊNCIAS BIBLIOGRÁFICAS/REFERENCES}

American Occupational Therapy Association. Occupational Therapy Practice Framework: Domain and Process (3rd Edition). American Journal of Occupational Therapy 68:S1-S48, 2014

Corrigan P. How stigma interferes with mental health care. American psychologist 59:614, 2004

Currie C, Zanotti C, Morgan A, Currie D, De Looze M, Roberts C, Samdal $\mathrm{O}$, Smith OR and Barnekow V. Social determinants of health and well-being among young people. Health Behaviour in School-aged Children (HBSC) study: international report from the the 2009/2010 survey 271, 2012

D’Agostino A, Giusti C and Potsi A. Gender and Children's wellbeing: Four Mediterranean countries in perspective. Child Indicators old, in the metropolitan area of Porto. It was found that young males who do not know individuals with $\mathrm{MH}$ problems and with a lower level of education perceive greater wellbeing. In the remaining variables under study, it was possible to observe differences in the levels of wellbeing, particularly being a young caregiver and living in municipalities with greater purchasing power per capita, and these factors seem to contribute to higher levels of wellbeing.

Wellbeing is an important element in human life, offering a feeling of fullness, happiness, and satisfaction with life. The sense of wellbeing seems to be closely related to the pleasurable participation of young people in occupations that are meaningful to them and their satisfaction with their life. In this way, occupational therapists must be aware of what the individual truly values and considers to be more beneficial for him or her to achieve as a goal, since wellbeing can be achieved only if the individual feels fully within himself or herself, if his or her occupational participation meets the standards defined by him or her, and if he or she feels satisfied with his or her own life. This understanding may have contributed one more step towards the development of intervention programs aimed at young people, which constitute an important complement for the prevention of $\mathrm{MH}$ problems and, consequently, for the improvement of health and wellbeing.

\section{AUTHORS' CONTRIBUTIONS}

Conceptualization, B.C., A.M., and M.T.; methodology, B.C., M.T., and V.S.; software, B.C. and M.T.; validation, all authors; formal analysis, B.C. and M.T.; research, B.C., M.T., and V.S.; writing-preparation of the original draft, B.C. and M.T.; writingproofreading and editing, V.S. and A.M. All authors have read and agreed with the published publication of the manuscript. 
Research 11:1649-1676, 2018

Department of Health \& Social Care. Care and Support Statutory Guidance. 2018

Disabato DJ, Goodman FR, Kashdan TB, Short JL and Jarden A. Different types of well-being? A cross-cultural examination of hedonic and eudaimonic well-being. Psychol Assess 28:471-482, 2016

Dodge R, Daly A, Huyton J and Sanders L. The challenge of defining wellbeing. International Journal of Wellbeing 2:222-235 2012

Ferreira C. Caraterização da Saúde Mental numa população jovem do concelho da Póvoa de Varzim - Tese de MEstrado, in Departamento de Ciência Política e do Comportamento, Universidade Fernando Pessoa, 2015

Figueiredo S, Trigueiro M and Simões-Silva V. Validação do WarwickEdinburgh Mental Well-being Scale (WEMWS) para a população Portuguesa - Tese de Licenciatura, in Terapia Ocupacional, Escola Superior de Saúde do Porto, 2019

Fundação Francisco Manuel dos Santos (FFMS). Poder de compra per capita: Territórios de Matosinhos, Gondomar e Valongo, PORDATA, Lisboa, 2017

Gomes MFP. Promoção da saúde das famílias com pessoas doentes mentais - Tese de Doutoramento, in Departamento de Enfermagem, Universidade Católica Portuguesa, 2014

Gómez-Baya D, Lucia-Casademunt AM and Salinas-Pérez JA. Gender Differences in Psychological Well-Being and Health Problems among European Health Professionals: Analysis of Psychological Basic Needs and Job Satisfaction. International journal of environmental research and public health 15:1474, 2018

Goodman FR, Disabato DJ, Kashdan TB and Kauffman SB. Measuring well-being: A comparison of subjective well-being and PERMA. The Journal of Positive Psychology 13:321-332, 2018

Guedes AdSM. Avaliação do impacto da perturbação mental na família, e implementação de um programa psicoeducacional Tese de Mestrado, Faculdade de Medicina da Universidade do Porto, 2011

Hammell KW. Opportunities for well-being: The right to occupational engagement. Can J Occup Ther 84:209-222, 2017

Haugland S, Wold B, Stevenson J, Aaroe LE and Woynarowska B. Subjective health complaints in adolescence. A cross-national comparison of prevalence and dimensionality. Eur J Public Health 11:4-10, 2001

Helena S. O Impacto da Doença Mental dos Pais nos seus Filhos. 2017

Hervás $\mathrm{G}$ and Vázquez C. Construction and validation of a measure of integrative well-being in seven languages: The Pemberton Happiness Index. Health and quality of life outcomes 11:66, 2013

Huppert FA. Challenges in defining and measuring well-being and their implications for policy, in Future directions in well-being pp 163167, Springer, 2017

Joseph S, Becker F and Becker S. Manual for measures of caring activities and outcomes for children and young people, Carers Trust, London, United Kingdom, 2012

Kaye-Tzadok A, Kim SS and Main G. Children's subjective well-being in relation to gender-What can we learn from dissatisfied children? Children and Youth Services Review 80:96-104, 2017

Keyes CL. The mental health continuum: From languishing to flourishing in life. Journal of health and social behavior:207-222, 2002

Keyes CL. Mental illness and/or mental health? Investigating axioms of the complete state model of health. Journal of consulting and clinical psychology 73:539, 2005

Keyes CL. Promoting and protecting mental health as flourishing: A complementary strategy for improving national mental health. American psychologist 62:95, 2007

Keyes CL. Mental well-being: International contributions to the study of positive mental health, Springer Science \& Business Media, 2012

Keyes CL, Dhingra SS and Simoes EJ. Change in level of positive mental health as a predictor of future risk of mental illness. Am J Public 
Health 100:2366-2371, 2010

Levin KA, Currie C and Muldoon J. Mental well-being and subjective health of 11- to 15-year-old boys and girls in Scotland, 1994-2006. Eur J Public Health 19:605-610, 2009

Lindsey LL. Gender roles: A sociological perspective, Routledge, 2015

Local Government Association. Meeting the health and wellbeing of young carers, Local Government Association, London, 2018

Maia I, Trigueiro M and Simões-Silva V. Validação do Pemberton Happiness Index (PHI) para a população Portuguesa - Tese de Licenciatura, in Terapia Ocupacional, Escola Superior de Saúde do Porto, 2019

Marôco J. Análise Estatística com o SPSS Statistics.: 7a edição, ReportNumber, Lda, 2018

Masten AS and Reed M-GJ. Resilience in development. Handbook of positive psychology:74-88, 2002

Matos AP, André RS, Cherpe S, Rodrigues D, Figueira $C$ and Pinto AM. Estudo Psicométrico preliminar da Mental Health ContinuumShort Form-for youth numa amostra de adolescentes portugueses. Psychologica:131-156, 2010

Matos M. Dados Nacionais 2018 - A Saúde dos Adolescentes Portugueses Após a Recessão. 2018

Mmari K, Blum RW, Atnafou R, Chilet E, De Meyer S, El-Gibaly O, Basu S, Bello B, Maina B and Zuo X. Exploration of gender norms and socialization among early adolescents: The use of qualitative methods for the Global Early Adolescent Study. Journal of Adolescent Health 61:S12-S18, 2017

Mostafa T and Ploubidis G. Millennium Cohort Study Sixth Survey 20152016: Technical Report on Response (Age 14). London: UCL Institute of Education, Centre for Longitudinal Studies, 2017

Muñoz LG, Modroño PR and Domínguez-Serrano M. Too Much Family and Too Much Gender Inequality: Women's and Men's Total Work in Mediterranean Countries. Gender and Well-Being: The Role of Institutions Routledge, London, 2016

Muñoz LG, Serrano MD, Sanz YR and Modroño PR. Aprendiendo A Trabajar Ya Cuidar De Forma Diferenciada: Género Y Capacidad En Los Jóvenes Andaluces. 2008

National Center Social Research. Predictors of Wellbeing, Department of Health, 2013

National Institute for Clinical Excellence. Promoting young people's social and emotional wellbeing in secondary education, Clinical Guidance, 2009

Pizzi MA and Richards LG. Promoting Health, Well-Being, and Quality of Life in Occupational Therapy: A Commitment to a Paradigm Shift for the Next 100 Years. Am J Occup Ther 71:7104170010p7104170011-7104170010p7104170015, 2017

Pollard EL and Lee PD. Child well-being: A systematic review of the literature. Social Indicators Research 61:59-78, 2003

Prazeres V, Laranjeira A and Oliveira V. Saúde dos jovens em Portugal: elementos de caracterização. Direcção-Geral da Saúde, 2005

Ringdal R, Bradley Eilertsen M-E, Bjørnsen HN, Espnes GA and Moksnes UK. Validation of two versions of the Warwick-Edinburgh mental well-being scale among Norwegian adolescents. Scandinavian journal of public health 46:718-725, 2018

Ryan RM and Deci EL. On happiness and human potentials: A review of research on hedonic and eudaimonic well-being. Annual review of psychology 52:141-166, 2001

Savoye I, Moreau N, Brault M-C, Levêque A and Godin I. Well-being, gender, and psychological health in school-aged children. Archives of public health 73:52, 2015

Seligman ME. Flourish: A visionary new understanding of happiness and well-being, Simon and Schuster, 2012

Sheldon KM, Corcoran M and Prentice M. Pursuing Eudaimonic Functioning Versus Pursuing Hedonic Well-Being: The First Goal Succeeds in Its Aim, Whereas the Second Does Not. Journal of Happiness Studies 20:919-933, 2019 
Slade M. Mental illness and well-being: the central importance of positive psychology and recovery approaches. BMC health services research 10:26, 2010

Tamir M and Gross JJ. Beyond pleasure and pain? Emotion regulation and positive psychology. Designing positive psychology: Taking stock and moving forward:89-100, 2011

Tennant R, Hiller L, Fishwick R, Platt S, Joseph S, Weich S, Parkinson J, Secker $J$ and Stewart-Brown S. The Warwick-Edinburgh mental well-being scale (WEMWBS): development and UK validation. Health and Quality of life Outcomes 5:63, 2007

The Children's Society. The Good Childhood Report 2018, The Children's Society, London, 2018

The Children's Society. Shaping our Future: Improving Assessment and Support for Young Carers Transition to Adulthood Report, Department of Health and Social Care, England, 2019

The Children's Society. Supporting young carers and their families: An introductory guide for professionals., The Children's Society, 2017

UNICEF Office of Research. Child Well-being in Rich Countries: A comparative overview, Innocenti Report Card 112013

UNICEF Office of Research. Building the future: Children and the sustainable development goals in rich countries. Innocenti Report Card 14, UNICEF Office of Research-Innocenti, Florence, 2017

World Health Organization. The European Mental Health Action Plan. 2013

World Medical Association. Proposed revision of the Declaration of Helsinki. Bulletin of medical ethics:18-22, 1999 